\title{
Intrinsic Motivation and Job Involvement on Employee Retention: Case Study - A Selection of Eastern Cape Government Departments
}

\author{
Sipho Mgedezi \\ Raymond Toga \\ Themba Mjoli \\ Department of Industrial Psychology, University of Fort Hare, Private Bag X1314, Alice, 5700, South Africa \\ Email: raytoga@gmail.com
}

\section{Doi:10.5901/mjss.2014.v5n20p2119}

\section{Abstract}

The study examines the relationship between intrinsic motivation and job involvement, with employee retention acting as a mediating variable. To succeed in its mission, every company must be able to retain its key employees. The independent variables of the study were intrinsic motivation and job involvement, while employee retention is the dependent variable. Data was gathered from a convenience sample of 160 employees from selected government departments in East London and Zwelitsha, Eastern Cape province. A four-part questionnaire was used for data collection. The measuring instruments were a self-designed questionnaire to measure the biographical and occupational data, and a questionnaire developed to measure intrinsic motivation (Intrinsic Motivation Inventory) with a Cronbach alpha $=0.81$. To measure job involvement, Kanungo's (1982) 10-item five-point Likert-type rating scale was used (Cronbach's alpha $=0.74$ ). To measure employee retention was measured using the cumulative Michigan Organizational Assessment two-item questionnaire (Camman, Fichman \& Klesh, 1979) and a third assessment item from Landau and Hammer (1986). Data analysis was done by means of the Pearson Product Moment Correlation technique, and Multiple Regression analysis. The results obtained from this study showed that there is a significant positive association between intrinsic motivation, job involvement and employee retention. The results further showed that employee's intrinsic motivation and job involvement have an influence on employee's intention to quit. The results further showed that intrinsic motivation is the strongest predicator of employee retention, followed by job involvement. The practical implications of this study mainly relate to employee retention or prevention of a high rate of labour turnover.

Keywords: intrinsic motivation, job involvement, employee retention

\section{Introduction}

In today's rapidly changing corporate environment, organizations seek out to maximize the potential of their human resources to stay ahead of the fierce competition and survive in the middle of the quest. Well motivated and involved workforce feels that organization value them and they are playing an essential role within their organization which significantly enhance both employees as well as organizational performance (Fossey \& Harvey, 2010). Motivated and committed employees with high levels of job involvement are considered as an important asset to an organization and keeping the employee motivation, commitment and job involvement up is always rewarding to a business as motivated and involved employees are more productive and less labour turnover (Fossey \& Harvey, 2010). An organization that offers recognition such as 'thank you', 'you're worth it' ensures that its employees feel that they are of high standard, thus promoting employee motivation and high involvement (Brown, 2004).

The globalization and technical advancements have created the high demand for motivated and involved skilled people. According to McKinsey Global Institute's report from 2012, in advanced economies the demand is growing faster than supply. In the wake of skills shortages organisations are now focused on acquiring techniques that bring out high employee performance. These techniques to achieve high performance are not the same for all organisations, even if they are competitors in the same field of business (Pesamaa, Shoham \& Ruvio, 2011). In these conditions we can say that the greatest challenge for an organization is how to attract, train, motivate and retain the highly qualified and productive employees. They can provide competitive advantage to the organisations today and in future.

Losing skilled and productive employees can be very harmful to the organization's productivity and success. A recent published meta-analysis covering trends of skilled employees emphasize low turnover rates on performance as well as covering its predictors (Hancock, Allen, Basco, McDaniel \& Pierce 2013). Most of these predictors cover how 
replacement process tends to be expensive and long. Even when the replacement is found, it usually takes time until new employees become productive again. A highly skilled motivated and involved person typically chooses carefully whether or not to work for a company. Usually the employees bring high level of competence and expertise into the organization and expect something in return if they are to remain with the organization. They are therefore motivated by different things and based on their motivation they choose whether or not to give their best effort (Hancock et al., 2013).

Has the lack of proper management to engage and intrinsically motivate their workforce influenced employee's intent to quit within the current South African climax? Evidently high turnover contaminates the organization through a decline in innovation, dense service delivery, and imprudent execution of new programs. Samuel and Chipunza (2009) advocates that such action can intensely affect the ability of organizations to advance in today's competitive economy, rendering even the most desirous organisations incapable of prospering due to their failure to retain the talented workforce. Less engaged and intrinsically motivated workforce is force to leave an organization and thus present a great threat to an organizations' success (Chungtai, 2008). This justifies why developing adequate interventions to retain talented employees has become important. The South African Public Service is an employer of 13.1 million citizens (DPSA annual report, 2010). Between the 2003-2007 financial period, head of departments' turnover rate was 25\% (The Public Service Commission, 2008). The implication of this turnover was due to poor service delivery. The annual turnover rate for $2009 / 2010$ financial period by all salary bands in all government departments was $11.7 \%$, and by critical occupation 3.1\%. This means that in a year, government lost over 130800 valuable employees, 10900 a month, or 363 a day. Government employees complain of begin de-motivated and lack of control over their work. Nowadays, competition between public and private sector is very stiff, it aids high rate of turnover. To remedy this situation, government must investigate what motivates its workforce and what keeps them involved in their jobs.

After considering what was mentioned above, the intention of this study is to offer knowledge that may explain why some employees choose to leave and why some choose to stay with their organization. We see that long term relationship between the organization and employee will depend on employee's motivation and involvement at workplace. Therefore this study seeks to investigate the relationship between intrinsic motivation and job involvement on employee retention in government departments in East London and Zwelitsha. A key question to be addressed is whether this approach is effective and appropriate for South Africa in the current context.

The main essential objectives of this study are to determine the relations between intrinsic motivation and job involvement, on one hand and employee retention on the other. It also seeks to investigate method used by government department on retaining talented employees and to explore the significant interaction between intrinsic motivation and job involvement, on one hand and employee retention, on the other. Based on the above statement and literature review the following hypotheses can be formulated:

$\mathrm{H}_{1}$ : There is a positive relationship between intrinsic motivation and employee retention

$\mathrm{H}_{2}$ : There is a positive relationship between job involvement and employee retention

$\mathrm{H}_{3}$ : There is a positive interaction between intrinsic motivation and job involvement which impacts employee retention

The literature provides detailed information on how talented employees are retained through involvement and motivation. Substantial research about employee retention has been conducted in Western world countries with most likely stable economic development (Ramlall, 2004). This study, therefore, seeks to be of significant use to the selected department in the Eastern Cape Provincial Government towards developing effective strategies that can improve the level of employee motivation and job involvement and thus reduce employee turnover. In line with that, this study will enable organisations and department in retaining existing employees who are competent and committed on their jobs; ensuring that they are able to achieve good quality service delivery to their clients and communities and thus achieve their organizational mandate; involving employees in every aspect of their jobs, which would result in committee workforce at all levels; and assuring department that the implemented retention interventions will eliminate any intention to quit that employee might considering, thus remaining loyal.

\section{Literature Review}

\subsection{Intrinsic motivation}

Motivations conceptually explain reasons to why individuals take on certain acts. Lincoln and Kelleberg (1990) argued that rewards offered by an organization can influence employees' attitudes towards their job and organization they work in. Rewards can be intrinsic and extrinsic. Intrinsic rewards come from the work itself like sense of achievement, appreciation, challenge, variety and autonomy. Extrinsic rewards are tangible rewards like pay, benefits, promotion, 
security and work environment. Judge, Piccolo, Podsakoff, Shaw and Rich (2010) study has conducted meta-analysis of 120years of research and has synthesized the findings from 92 quantitative studies. The combined dataset included over 15000 individuals and 115 correlation coefficients. According to this study, there is very weak (less than 2\%) dependency between salary and job satisfaction. Study showed that "the average level of job satisfaction remains relatively stable across studies, regardless of the change in mean pay level." (Judge et al., 2010, p.162). Gallup's study including 1.4million employees from 192 organisations across 49 industries and 34 nations reports no difference in engagement based on pay level (Gallup, 2011).

Even though some authors have shown that even extrinsic rewards impact employee retention, because of the above findings, we will focus on intrinsic rewards alone. Another reason is that it has been shown that intrinsic rewards have greater impact on employee retention than extrinsic rewards (O'Driscoll \& Randall, 1999). This conclusion was confirmed by Cho and Perry (2012) research which showed that intrinsic motivates relates to employee engagement levels three times more strongly than extrinsic motivates. Lawler (1970) defines intrinsic motivation as the degree to which an employee is motivated to perform well because it will result in a good feeling and subjective rewards like feelings of growth, high self-esteem, competence, autonomy etc. Deci (1973) defines intrinsic motivated activities as activities which a person does for no apparent reward but the activity itself or the feelings which results from the activity. Together with Ryan he defined self-determination theory (SDT) in 1985. They state that employees will be intrinsically motivated if their basic need for acceptance, autonomy and relatedness is satisfied.

According to Lawler (1973), an employee is intrinsically motivated to perform well as long as he/she expects that his/her job will provide the feedback he/she values. This fits well into the expectancy theory approach to motivation (Vroom, 1964). According to this theory, people are motivated to work if they believe that their efforts in the workplace will result in the outcome they expect. To effectively motivate and retain employees, management need to deal with each person one at a time, asking question of, listening to, and working together one-on-one. Good management, therefore, is the one that will help talented people find satisfaction in their work, and satisfaction is the key to an employee's decision to stay or leave the organization (Dirks \& Skarlicki, 2009; Cho \& Ringquist, 2011; Chun \& Rainey, 2005; Colqitt, Scott, LePine, 2007; Grant \& Sumath, 2009).

\subsection{Job involvement}

Job involvement refers to how people perceive their jobs in relation to (i) the working environment, (ii) the job itself, and (iii) how their work and life are integrated (Hirschfield \& Field, 2000). Having low involvement contributes to employees' feelings of alienation of purpose, alienation in the organization or feeling of separation between what the employees see as their "life" and the job they do. Job involvement can also be defined as the extent to which an individual is personally involved with his or her work role (wikianswers.com). Kanungo (1982) views job involvement as a cognitive or belief state of psychological identification with one's job. In other words, this approach suggests that an individual's psychological identification with a particular job depends on the saliency of his or her needs and the perceptions he or she has about the need satisfying potentialities of the job (Kanungo 1982). Brown (1996) argues that job involvement will be highest when the work environment: makes one believes that one's work is meaningful; offers control over how work is accomplished; maintains a clear set of behavioral norms; makes feedback concerning completed work available; and provides supportive relations with supervisors and co-workers. Many theorists have hypothesized that highly involved employees will put forth substantial effort towards the achievement of organizational objectives and are less likely to turnover.

Argyris (1957) and McGregor (1960) saw job involvement as a means of aiding productivity and of creating work situations in which there would be better integration of individual and organizational goals. Marcson (1960) presented an argument and findings suggesting that one of the best ways to increase productivity in organisations was to provide employees with jobs that are more demanding and challenging. Recent studies of job involvement show that such involvement enhances the individual's satisfaction, while at the same time increasing productivity for the organization (Hall \& Lawler 2000). Mohr and Zoghi (2008)'s study shows that job satisfaction was positively correlated with highinvolvement practices and that satisfied employees are more involved in their work.

\subsection{Employee retention}

In slightly more than a decade (1988-2000), the eminent issue for companies was one of attracting and retaining people with the skills necessary to do the work. The situation became even more complex during $2001-2009$ period as an economic meltdown forced thousands companies to cut back or downsize their employee populations. During that period 
alone, more than millions jobs have been eradicated leaving a scenario of lost trust, eroded loyalties, financial demise, growing employee cynicism and diminished productivity. Employee stress levels have escalated as morale and creativity plummet, while simultaneously, the cost of absenteeism and medical related expenditures have risen. Further, companies are now indicating that product quality is beginning to suffer; customer satisfaction is dropping and many organizations are beginning to experience a significant increase in turnover of key talent--especially amongst those individuals considered most 'crucial' to the downsized organization (Jo, 2008; Lyons, Alarcon \& Nelson 2010; Ramesh, 2007; Min, 2007; Sullivan, 2009).

In a sense, the manager's function is that of a "catalyst" and as with all catalysts, the manager's function is to speed up the reaction between two substances, thus creating the desired end product (Buckingham and Coffman, 1999). Specifically the managers improve or promote employee performance by speeding up the reaction between the employee's talents and the company's goals, and between the employee's talents and the customer's needs. When hundreds of managers play this role well, the company becomes strong, one employee at a time. In today's slimmeddown business world, most managers shoulder other responsibilities: they are expected to be subject matter experts, individual superstars and leaders in their own right. These are important roles which managers execute with varying styles and degrees of success, but when it comes to the manager aspect of their responsibilities, "great managers" excel at the catalyst role. What we're faced with today, is an extremely dynamic and volatile work environment marked by continued turbulence in the economy. Managers face a difficult challenge of motivating and retaining employees in an environment of increased uncertainties (Mitchell, 2002). Essentially, no organization, profession or community has been unaffected by the continuing series of layoffs, dot com failures and restructurings. At the same time, jobs are being created at unprecedented rates.

\section{Methodology}

\subsection{Research approach}

The researchers made use of use of a quantitative research design, which can be defined, according to De Vos, Strydom, Fouche and Delport (2007), as an investigation into a social or human problem, based on testing a theory composed of variables. This is measured with numbers and analyzed with statistical procedures in order to establish whether the prognostic generalizations of the theory hold true. The rationale behind this is that we have chosen to develop hypotheses and a theoretical model which can be verified through quantitative research method. The emphasis on quantifying observation follows the ideas that our problem is relatively well known in the theory.

\subsection{Participants}

A convenience sample $(n=160)$ of employees in the South African Police Service - Eastern Cape Head office and Department of Rural Development and Land Reform - East London Shared Service Centre were selected. Next, the characteristics of the study population will be described. The population consisted of $48 \%$ male participants and $52 \%$ female participants. Furthermore, the sample comprised of Xhosa speaking (53\%), Afrikaans speaking (14\%), English speaking (12\%), Sotho speaking (7\%) and Zulu speaking (16\%) participants, of whom majority $70 \%$ were married, $14 \%$ were single, $8.5 \%$ widowed and $6.9 \%$ were divorced participants. The ages of the participants were between the ages of 18-25years (18\%), 26-35years (47\%), 36-45years (21\%), 46-55years (8\%), 56years and older (5\%). Most participants had two to five years' experience 78\%, and most indicated a diploma as their level of qualification (39\%) and (18) had a certificate.

\subsection{Measuring instruments}

The following measuring instruments were used for the purpose of empirical study. The measuring instruments were a self-designed questionnaire to measure the biographical and occupational data, and a questionnaire developed to measure intrinsic motivation (Intrinsic Motivation Inventory) with a Cronbach alpha $=0.81$. To measure job involvement, Kanungo's (1982) 10-item five-point Likert-type rating scale was used (Cronbach's alpha $=0.74)$. To measure employee retention was measured using the cumulative Michigan Organizational Assessment two-item questionnaire (Camman, Fichman \& Klesh, 1979) and a third assessment item from Landau and Hammer (1986). 


\subsection{Research procedure}

Ethics approval was obtained by the ethics committee of the participating University of Fort Hare. The researchers requested permission from the South African Police Service - Eastern Cape Head office and Department of Rural Development and Land Reform - East London Shared Service Centre management to conduct the research. A meeting was scheduled with the head of each department to discuss how the questionnaire would be distributed, completed and collected with the least interruption of duties. The researchers took the questionnaires to each head of the department at the arranged time and waited for participants to complete them. Information was provided to the reason and focus of the study. Anonymity was ensured and participants could withdraw at any stage.

\subsection{Data Analysis}

The researcher rearranged and sorted the information collected using the Statistical Package for Social Sciences (SPSS), which was followed by selecting, differentiating and breaking down of information into components related to each other. The statistical analysis used included descriptive statistics, measure of central tendency and dispersion, inferential statistics in the form of the Pearson product moment correlation, Pearson Chi-square and the Multiple linear regression. The aim of the data analysis was to check the testability of the research questions and the hypothesis of the study. The researcher used inferential statistics to determine the relationship between intrinsic motivation and job involvement on employee retention.

\section{Empirical Findings and Discussion}

\subsection{Descriptive statistics}

The descriptive statistics in the form of arithmetic means and standard were computed from measurement instruments of intrinsic motivation, job involvement and employee retention questionnaires. These are presented in Table 1 together with the number of cases (sample size) that responded to each questionnaire.

Table 1: Mean, Standard Deviation and total number of case in relation to intrinsic motivation, job involvement and employee retention.

\begin{tabular}{|l|c|c|c|}
\hline Variable & N & Mean & Standard Deviation \\
\hline Intrinsic Motivation & 130 & 3.1077 & 0.39737 \\
\hline Job Involvement & 130 & 2.980 & 0.4475 \\
\hline Employee Retention & 130 & 3.003589 & 0.735756 \\
\hline
\end{tabular}

The level of intrinsic motivation, job involvement and employee retention among the sample of 160 employees in the South African Police Service - Eastern Cape Head office and Department of Rural Development and Land Reform - East London Shared Service Centre is depicted in table 1. The results indicate that intrinsic motivation has a mean of 3.1077 and a standard deviation of 0.39737 . The results further indicate that the mean of job involvement is 2.980 and the standard deviation is 0.4475 . The results also indicate that employee retention has a mean of 3.0035 and a standard deviation of 0.735756 .

\subsection{Inferential statistics}

This study ought to investigate the relationship between intrinsic motivation and job involvement, on the one hand, and employee retention, on the other. Inferential statistics, specifically Pearson's Chi-square and Pearson's Product Moment correlation coefficient was computed to determine the association and the relationships among the variables. 
Table 2: The association among the variables intrinsic motivation, job involvement and retention

\begin{tabular}{|l|c|c|c|}
\hline Overall Employee involvement and retention & Value & df & Asymp. Sig. (2-sided) \\
\hline Pearson Chi-square & $357.793^{\mathrm{a}}$ & 200 & .000 \\
\hline Likelihood Ratio & 228.841 & 200 & .079 \\
\hline Linear-by-Linear Association & 9.914 & 1 & .002 \\
\hline N of Valid Cases & 130 & & \\
\hline Overall Intrinsic motivation and Retention & Value & df & Asymp. Sig. (2-sided) \\
\hline Pearson Chi-square & $271.587 \mathrm{a}$ & 130 & .000 \\
\hline Likelihood Ratio & 171.066 & 130 & .009 \\
\hline Linear-by-Linear Association & .133 & 1 & .715 \\
\hline N of Valid Cases & 130 & & \\
$P<0.05$ level of significance & &
\end{tabular}

The first null hypothesis of the study $\left(\mathrm{H}_{0}\right)$ was stated as, "there is no positive significant between intrinsic motivation and employee retention" and the corresponding alternative hypothesis $\left(\mathrm{H}_{1}\right)$ was that, "there is a positive significant between intrinsic motivation and employee retention". A Chi-square test of association was enforced by cross tabulating the three variables. The results indicated a Chi-square value of 271.587 and 130 degree of freedom with a probability value of 0.000 . Since the $p$-value is less than 0.05 , this shows that two variables are significantly and highly positively correlated. This leads to a rejection of the null hypothesis and acceptance of the alternative hypothesis.

The second null hypothesis of the study $\left(\mathrm{H}_{0}\right)$ was stated as, "there is no positive significant between job involvement and employee retention" and the corresponding alternative hypothesis $\left(\mathrm{H}_{1}\right)$ was that, "there is a positive significant between job involvement and employee retention". The Chi-square value for employee involvement is $\mathrm{x}^{2}(4)=$ $357.793^{\mathrm{a}}$ with an association p-value of 0.000 . The outcome provides strong evidence that there is an association between employee involvement and employee retention. This also leads to a rejection of the null hypothesis and acceptance of the alternative hypothesis. Employee job involvement strongly influences employee retention amongst employees in the public sector departments. For employees to be loyal to their organisations, they must be constantly involved in the organization. According to Smit and Cronje (2012) employee involvement is one of the best strategies for employee retention.

\subsection{Correlation analysis}

In addition to the Chi-square test of association, Pearson correlation analysis was carried out to determine the significance; strength and direction of the relationship between intrinsic motivation and job involvement, on one hand and employee retention, on the other.

Table 3: Correlation between intrinsic motivation and employee retention

\begin{tabular}{|r|c|c|}
\hline & Employee retention & Job involvement \\
\hline Turnover Pearson & 1 & $-.277^{\star \star}$ \\
Sig. (2-tailed) & 130 & .001 \\
$\mathrm{~N}$ & & 130 \\
\hline
\end{tabular}

Table 3.1: Correlation between motivation and retention

\begin{tabular}{|r|c|c|}
\hline & Motivation & Retention \\
\hline Motivation Pearson & 1 & 0.32 \\
Correlation & & .717 \\
Sig. (2-tailed) & & 130 \\
$\mathrm{~N}$ & 130 & 1 \\
\hline Retention Pearson & 0.32 & \\
Correlation & & 130 \\
Sig. (2-tailed) & .717 & \\
$\mathrm{~N}$ & 130 & \\
\hline
\end{tabular}


There results above indicate that there was a negative and statistically significant relationship only between employee job involvement and turnover $(r=-0.277 ; p<0.001)$. This means that high values of one variable are associated with less values of the other variable. Specifically, highly involved employees in an organization are less likely to quit. This might be because they are motivated and committed to the organization. According to Gallup's (2013) study "The State of the American Workplace", 70\% of American workers are "not involved" in their workplace. They are emotionally disconnected from their workplace and likely to be unproductive and some leave the organization. In the report it is estimated that "uninvolved or actively unengaged" workers cost the U.S between $\$ 450$ billion to $\$ 550$ billion dollars a year in loss. These recently published numbers show alarming importance of having motivated and engaged employees at the work place.

There have been many studies that investigated factors that impact employee turnover (Hancock et at., 2013). Job involvement is often identified as main predictor of employee turnover (Boal \& Cidambi, 1984). Hence, organisations that are concerned about employee retention should consider increasing job involvement among their employees. According to Hancock et al., (2013) involved employees will mostly likely stay longer periods with the organization and tell favorable things about the organization. There was a significant correlation between intrinsic motivation and employee retention $(r=$ 32; $p<0.717$. Yang and Kassekert's (2010) recent analysis of the effects of civil service overhaul, contracting out, and managing-for-results on employee satisfaction is a good example of how organizational characteristics and change could be tied to employee attitudes and motivation. Intrinsic motivation is positively associated with employee satisfaction, whereas it is negatively related to intent to leave. Retention is also influenced by many factors other than motivation alone. For instance, if a person is intrinsically motivated, it does not guarantee that, that particular person will stay with the organization. One can be motivated by the work environment and not motivated by factors which might lead him to leave the organization.

\section{Conclusion}

The study sought to investigate the relationship between intrinsic motivation and job involvement, on the one hand and employee retention, on the other. This research adds empirical evidence for the importance of an intrinsically motivated and engaged workforce. Intrinsic motivation is positively associated with job involvement, whereas it is negatively related to intent to quit. This means that a happy motivated and engaged workforce is the only key to employee's decision to either stay or leave the organization. The results also indicated that intrinsic motivation is the strongest predictor of employee retention, followed by job involvement. More important, regarding job involvement, it interacts with intrinsic motivation in a way that produces salutary results for organizations. The main practical implication of this study mainly relate to employee retention or prevention of a high rate of labour turnover. To succeed in its mission, every company must be able to retain its key employees. Committed, motivated and involved employees are likely to be strongly associated with employee retention. To curb the high rate of employee turnover in government departments may therefore necessitate strategies to increase employee's intrinsic motivation, and therefore retention, companies must promote job involvement. According to Maslow' Hierarchy of Needs Theory, such a strategy may imply the need to provide for the satisfaction of the employee's lower-order needs.

It is, however, also important to note some of the limitations of this study. The sample used for this study was from only few selected government departments in the Eastern Cape Province. Therefore it may not be quite justifiable to generalize the findings to other provincial government departments in the entire country. Only self-administered questionnaires were used to gather data. This raises the possibility of common method variance. Future researchers should focus on the above limitations of this study and thus improve the generalisability of the study. It is important that some future studies should use qualitative rather than quantitative methodologies like this study. This will ensure triangulation of research results. Future research should also incorporate an investigation to determine the effect of demographic variables on employee retention in order to predict turnover tendencies among various groups.

\section{References}

Argyris, C. (1957). Personality and Organization, New York: Harper Collins.

Boal, K., \& Cidambi, R. (1984). Attitudinal correlates of turnover and absenteeism: A meta analysis. Paper preseted at the meeting of the American Psychological Associatio, Toronto, Canada.

Brown, S. P. (1996). A meta-analysis and review of organizational research on job involvement. Psychological bulletin, $120(2), 235$.

Brown, W. (2004). Organizational mission as a core dimension in employee retention. Journal of Park and Recreation Administration.

Cammann, C., Fichman, M., Jenkins, D., \& Klesh, J. (1979). The Michigan Organisational Assessment Questionnaire. Unpublished manuscript, University of Michigan, Ann Arbor, Michigan.

Cho Yoon Jik \& Perry James L. (2012) Intrinsic Motivation and Employee Attitudes Role of Managerial Trustworthiness, Goal 
Directedness, and Extrinsic Reward Expectancy Review of Public Personnel Administration December 2012 vol. 32 no. $4382-$ 406

Cho, Y. J., \& Ringquist, E. J. (2011). Managerial trustworthiness and organizational outcomes. Journal of Public Administration Research and Theory, 21(1), 53-86.

Chun, Y. H., \& Rainey, H. G. (2005). Goal ambiguity and organizational performance in U.S. federal agencies. Journal of Public Administration Research and Theory, 15, 529-557.

Chughtai, A. A. (2008). Impact of Job Involvement on In-Role Job Performance and Organizational Citizenship Behaviour. Institute of Behavioural and Applied Management. Retrieved from http://www.emeraldinsight.com

Colquitt, J. A., Scott, B. A., \& LePine, J. A. (2007). Trust, trustworthiness, and trust propensity: A meta-analytic test of their unique relationships with risk taking and job performance. Journal of Applied Psychology, 92, 909-927.

Deci, E. L. (1973). Intrinsic Motivation.

De Vos, A.S., Strydom, H., Fouche, C.B., \& Delport, C.S.L. (2007). Research at grass roots for the social sciences and human service professions. (3rd edn.). Pretoria, South Africa: Van Schaik Publishers.

Dirks, K. T., \& Skarlicki, D. P. (2009). The relationship between being perceived as trustworthy by coworkers and individual performance? Journal of Management, 35, 136-157.

Fossey, E. M., \& Harvey, C. A. (2010). Finding and sustaining employment: a qualitative meta-synthesis of mental health consumer views. Canadian Journal of Occupational Therapy, 77(5), 303-314

Gallup (2011) Majority of American Workers Not Engaged in Their Jobs http://www.gallup.com/poll/150383/majority-american-workersnot-engaged-jobs.aspx

Gallup (2013) The State of the American Workplace: Employee Engagement Insights for U.S. Business Leaders Accessed via http://www.gallup.com/strategicconsulting/163007/state-americanworkplace.aspx June 2013

Hall, D. T. \& Lawler, E. E. (2000). Job characteristics and job pressures and the organizational integration of professionals. Administrative Science Quarterly, 15, 271-281.

Hancock, J. I., Allen, D. G., Bosco, F. A., McDaniel, K. R., \& Pierce, C. A. (2013). Meta-analytic review of employee turnover as a predictor of firm performance. Journal of Management, 39(3), 573-603. 44

Hisrchfeld, R. R. \& Field, H. S. (2000). Work centrality and work alienation: Distinct aspects. Of a general commitment to work. Journal of Organisational Behavior, 21(7), pp.789-800.

Jo, V.H. (2008). Voluntary turnover and women administrators in higher education. Higher Edu Journal, 56: 565-582.

Judge, T. A., Piccolo, R. F., Podsakoff, N. P., Shaw, J. C., \& Rich, B. L. (2010). The relationship between pay and job satisfaction: A meta-analysis of the literature. Journal of Vocational Behavior, 77(2), 157-167.

Kanungo, R. N. (1982). Measurement of Job and Work Involvement. Journal of Applied Psychology, 67(3): 341-349.

Landau, J., \& Hammer, T.H. (1986). Clerical employees' perceptions of intra organizational career opportunities. Academy of Management Journal, 29, 385-404.

Lawler, E. E. (1970). JOB ATTITUdES AND EMPLOYEE MOTIVATION: THEORY, RESEARCH, AND PRACTICE1. Personnel Psychology, 23(2), 223-237. Lawler III, E.E. (1973) Motivation in work organizations.

Lyons, J.B., Alarcon, G.M., \& Nelson, A.D. (2010). Employee Retention: A business Case for Engagement. 2d Lt. Frank Tartaglia Air Force Research.

Marcson, S. (1960). The scientist in American industry. New York: Harper.

McGregor, D. (1960). The Human Side of Enterprise. New York: McGraw-Hill Book Co., Inc.

Min, H. (2007). Examining sources of warehouse employee turnover. International Journal of Physical Distribution \& Logistics Management, 37 (5), 375-388.

Mitchell, Lawrence E. (2002). Corporate irresponsibility—America's newest export. New Haven \& London: Yale University Press.

Mohr, R. D., \& Zoghi, C. (2008). High-involvement work design and job satisfaction. Industrial and Labor Relations Review, 275-296.

O'Driscoll, Michael P., and Donna M. Randall. "Perceived organizational support, satisfaction with rewards, and employee job involvement and organizational commitment." Applied Psychology 48.2 (1999): 197-209.

Pesämaa. O., Shoham, A., \& Ruvio. A. (2011). Antecedents and consequences of innovativeness. Presented at 2011 AMS World Marketing Congress (WMC), July 19-23, France.

Ramlall, S. (2004). A Review of Employee Motivation Theories and their Implications for Employee Retention within Organizations. The Journal of American Academy of Business, 52 (8), 52-53.

Samuel, M.O. \& Chipunza, C. (2009). Employee retention and turnover: Using motivational variables as a panacea. African Journal of Business Management, 3(8), 410-415.

Smit, P.J \& Cronje, G.J. (2012). Management principles. A contemporary Edition for Africa. $3^{\text {rd }}$ ed. Juta, Cape Town.

Sullivan, J. (2009). Understanding Available Retention Strategies: Are You Prepared for Turnover Rates to Double?

Yang, K., \& Kassekert, A. (2010). Linking management reform with employee job satisfaction: Evidence from federal agencies. Journal of Public Administration Research and Theory, 20, 413-436. 